\title{
PELATIHAN PENGOLAHAN SUSU KEDELAI DALAM MENINGKATKAN PRODUKSI ASI DI DESA TANJUNG BERINGIN
}

\author{
Desri Meriahta Girsang ${ }^{1}$, Jelita Manurung ${ }^{1}$, Wira Maria Ginting ${ }^{1}$, Nadia Husna ${ }^{1}$ \\ ${ }^{1}$ Progaran Studi Gizi Fakultas Kesehatan Masyarakat, Institut Kesehatan Medistra Lubuk \\ Pakam
}

\author{
Jln. Sudirman No.38 Lubuk Pakam, Kabupaten Deli Serdang, \\ Sumatera Utara - Indonesia \\ *email korespondensi author: Desrimeriahta@outlook.com
}

DOI 10.35451/jpk.v1i1.709

\begin{abstract}
Abstrak
ASI dengan kualitas produksi yang sedikit tentu menjadi masalah bagi ibu yang sedang berada masa pasca nifas. Ada berbagai faktor yang menjadi penyebab seperti puting yang datar atau tenggelam, payudara ibu yang bengkak, teknik menyusui kurang tepat atau bahkan karena lidah bayi yang pendek. Kegiatan yang telah dilaksanakan ini merupakan suatu pelatihan yang bertujuan untuk memberikan informasi dan meningkatkan kemampuan dalam mengolah bahan pangan (kedelai) sehingga kandungan gizinya lebih meningkat serta lebih efisien dalam konsumsinya untuk capaian tujuan yaitu meningkatnya kualitas produksi ASI. Berbagai penelitian menyatakan bahwa susu kedelai dinilai mampu meningkatkan kualitas produksi ASI. Vitamin E yang terkandung dalam susu kedelai tidak hanya berperan untuk menjaga kesehatan kulit saja melainkan juga berperan dalam meningkatkan produksi hormon phytoestrogen yang dapat membantu kelenjar susu ibu dapat memproduksi ASI lebih banyak. Pengolahan susu kacang kedelai juga dinilai lebih efisien daripada konsumsi obat pelancar ASI yang notabene lebih sulit diperoleh terkhusus di daerah pedesaan. Pemilihan metode pelatihan pada kegiatan PKM ini adalah agar capaian tujuan PKM akan lebih efisien daripada pemberian informasi dengan metode penyuluhan. Pelatihan pengolahan susu kedelai dalam meningkatkan produksi ASI ini diharapkan dapat menjadi solusi bagi permasalahan ibu pasca nifas yang mengalami kurangnya produksi ASI. Jangka waktu pelaksanaan kegiatan PKM ini adalah selama 4 hari dengan jumlah sasaran 50 ibu pasca nifas yang berada di Desa Tanjung Beringin. Pada akhir kegiatan PKM, terdapat peningkatan kemampuan para ibu dalam pengolahan kacang kedelai menjadi susu kedelai.
\end{abstract}

Kata Kunci: Penyuluhan; ASI; Susu Kedelai

\begin{abstract}
Breast milk with low production quality is certainly a problem for mothers who are in the postpartum period. There are various factors that cause such as flat or drowning nipples, swollen breasts of the mother, inappropriate breastfeeding techniques or even the baby's short tongue. The counseling that has been carried out is a PKM activity that aims to provide information using the counseling method given to postpartum mothers about the importance of increasing breast milk production, one of which can be done by consuming soy milk. Various studies have stated that soy milk is considered capable of improving the quality of breast milk production. Vitamin E contained in soy milk not only plays a role in maintaining healthy skin but also plays a role in increasing the production of phytoestrogens which can help the mother's milk glands to produce more breast milk. Soybean milk is also considered to be more efficient than consumption of breastfeedingreleasing drugs, which is more difficult to obtain, especially in rural areas. The selection of the extension method in this PKM activity is so that the targets that can be reached are wider compared to providing information with the consultation method. It is hoped that the counseling on the benefits of soy milk in increasing breast milk production can be a solution to the problems of postpartum mothers who experience a lack of milk production. The implementation period of this PKM activity is 4 days with a target number of 50 postpartum mothers residing in Tanjung Beringin Village. At the end of this PKM, there was an increase in knowledge related to increasing breast milk production through consumption of soy milk.
\end{abstract}

Keywords: Counseling; Breastmilk; Soy Milk 
Received: 04 June 2021 :: Accepted: 30 June 2021 :: Published: 30 June 2021

\section{Pendahuluan}

Bagi bayi, Air Susu Ibu (ASI) merupakan makanan utama yang dibutuhkan. Kondisi inilah yang membuat ibu harus menyadari bahwa kualitas jumlah ASI harus diperhatikan agar bayi tidak mengalami kekurangan asupan. Baiknya kualitas produksi ASI akan memungkinkan ibu untuk memberikan ASI eksklusif (Hamilton, 2010)

World Health Organization (2018) menjelaskan bahwa rata-rata angka pemberian ASI eksklusif di dunia masih rendah yaitu sekitar 38\%.

Prevalensi pemberian ASI ekskusif di Indonesia hanya 42\%. Angka ini tergolong rendah bila dipertimbangkan bahwa ternyata sebanyak $96 \%$ perempuan di Indonesia ternyata menyusui anaknya. Sehingga disimpulkan bahwa pemberian makanan bayi masih kurang dan inilah yang menjadi penyebab tingginya permasalahan gizi yang terjadi termasuk stunting (Pramitasari, 2017)

Susu merupakan salah satu contoh golongan bahan makanan yang memiliki kandungan gizi bernilai tinggi dan cukup lengkap baik dari kandungan gizi makro maupun gizi mikronya. Zat gizi yang terkandung hampir sempurna dan cocok dikonsumsi sebagai pemenuhan kebutuhan (Budimarwanti, 2013)

Asam amino yang terkandung dalam kacang kedelai tergolong lengkap dan mirip dengan susu hewani hanya saja perlu disediakan dalam bentuk makanan siap konsumsi agar dapat disintesis dengan kecepatan memadai (Elida, 2019)

Selain asam amino, kacang kedelai juga mengandung isoflavon yang bermanfaat bagi kesehatan dalam meningkatkan metabolisme dalam tubuh serta mencegah kanker atas aktivitas antioksidan (Elika, 2018)

Ada beberapa cara yang dapat digunakan untuk meningkatkan kualitas produksi ASI dan pada kegiatan PKM ini teknik yang dilakukan adalah dengan mengadakan pelatihan pada ibu mengenai pelatihan pengolahan susu kedelai yang mana kedelai dianggap salah satu bahan makanan fungsional dan mudah diperoleh serta harganya yang tergolong murah sehingga pelaksanaannya mudah.

\section{Metode}

Metode yang dilakukan pada kegiatan pengabdian masyarakat ini adalah dalam bentuk pelatihan. Kegiatan ini dilakukan di Desa Tanjung Beringin. Dibentuk tim kerja dimana tim tersebut melakukan koordinasi pada pihak PKK kelurahan dalam perencanaan kegiatan pelatihan pengolahan susu kedelai kemudian ditetapkan jumlah pesertanya 50 orang. Kegiatan ini dilakukan pada tanggal 15-18 Februari 2021. Sebelum dilakukan pelatihan, akan diberikan pre test. Kegiatan pelatihan dimulai dengan memberikan materi terkait dengan menggunakan media booklet juga video serta dilakukan demonstrasi tahapan pembuatan susu kedelai yang diikuti dengan minum susu kedelai bersama. Akhir kegiatan PKM ini dilakukan post test untuk melihat kemajuan kemampuan secara teori dari sebelum sampai setelah diberikan pelatihan. Penutupan kegiatan PKM dilakukan bersamaan dengan pembagian bahan dasar untuk membuat susu kedelai sehingga dapat diolah mandiri di rumah masing-masing.

\section{Hasil dan Pembahasan}

Pengabdian Masyarakat yang telah terlaksana di Desa Tanjung Beringin yang dimulai pada tanggal 15 Februari 2021. Kegiatan yang dilakukan adalah pelatihan dengan keseluruhan peserta adalah ibu yang sedang menyusui.

PKM yang dilaksanakan dimulai dengan pre test dan diakhiri dengan pelaksanaan post test yang hasilnya dijabarkan pada tabel berikut:

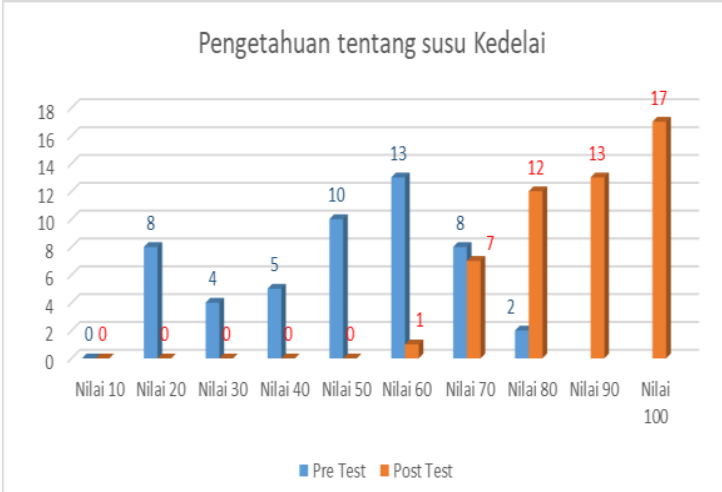

Gambar 1. Diagram Batang Pre-Post Test Pengetahuan Tentang Susu Kedelai pada Peserta PKM

Sebelum dilakukan pelatihan terlihat pada gambar 1 dimana ditunjukkan pengetahuan peserta tentang susu kedelai berada pada rentang skor nilai 20 - 80 dengan terbanyak memiliki skor 60 yaitu 13 orang $(26 \%)$. Setelah dilatih tentang susu kedelai, pengetahuan peserta berada pada rentang nilai 60 - 100 dan terbanyak memiliki nilai 100 pada 17 orang (34\%).

Selama ini para peserta hanya pernah menikmati susu kedelai dengan cara membeli dari penjual keliling ataupun dari toko dan supermarket. Pelatihan membuat susu kedelai belum pernah diperoleh. Hal tersebut terlihat padan nilai yang diperoleh pada pre test dimana sebagian besar nilainya ada pada rentang kurang yaitu $\leq 50$. Hal ini menunjukkan bahwa pengetahuan atau pemahaman kaum ibu tentang susu kedelai dan cara pembuatannya masih rendah. 
Received: 04 June 2021 :: Accepted: 30 June 2021 :: Published: 30 June 2021

Padahal susu kedelai Susu kedelai merupakan minuman yang bergizi tinggi, terutama kandungan proteinnya. Selain itu susu kedelai juga mengandung lemak, karbohidrat, kalsium, fosfor, zat besi, provitamin A, vitamin B kompleks (kecuali B12), dan air Susu kedelai harganya lebih murah daripada susu hewani (Budimarwanti, 2013)

Susu kedelai yang mengandung protein nabati tidak kalah gizinya dengan susu yang berasal dari hewan (susu sapi). Komposisi gizi di dalam susu kedelai dan susu sapi.

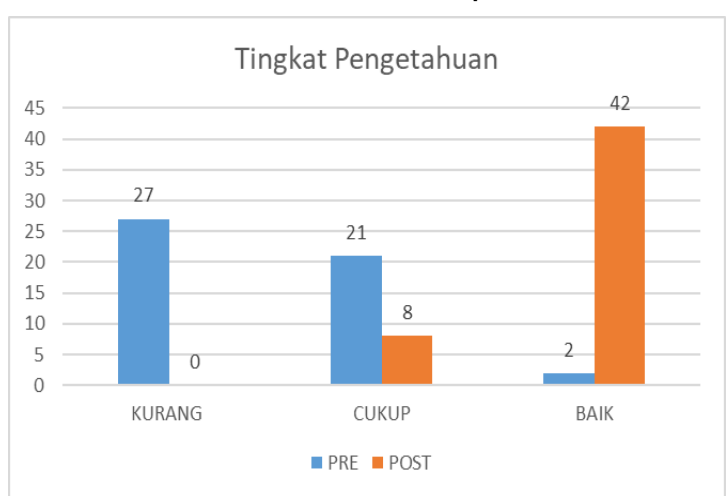

Gambar 2. Diagram Batang Tingkat Pengetahuan tentang Susu Kedelai

Berdasarkan gambar 2 menunjukkan bahwa nilai pre test sebagian besar pengetahuan pada kategori kurang atau berada pada skor $\leq 50$ yaitu 27 orang (54\%). Sedangkan nilai post test mayoritas kategori baik pada skor $\geq 80$ yaitu 42 orang ( $84 \%)$.

\section{Kesimpulan}

Kegiatan pengabdian masyarakat melalui pelatihan pengolahan susu kedelai dengan tujuan meningkatkan kualitas produksi ASI dapat disimpulkan terjadi peningkatkan pengetahuan ibu di Desa Tanjung Sari kedelai beserta manfaatnya dan cara pengolahan susu kedelai. Peningkatan pengetahuan ibu sudah terlihat pada hasil post test yang rata-rata nilainya emningkat dari nilai pre test serta saat peserta mampu mengajarkan pembuatan susu kedelai kepada ibu-ibu PKK yang lainnya.

\section{Ucapan Terima Kasih}

Pengabdian masyarakat ini terlaksana atas kerjasama dan komitmen bersama antara tim pelaksana PKM serta para peserta yang telah terlibat dalam terselenggaranya kegian pengabdian masyarakat sehingga tujuan bersama dapat tecapai.

\section{Daftar Pustaka}

Budimarwanti. (2013). Komposisi dan Nutrisi pada Susu Kedelai. Universitas Negri Yogyakarta.
Hamilton. (2010). Dasar-dasar Keperawatan Maternitas. Jakarta: EGC.

Pramitasari. (2017). Perawatan Payudara Dilengkapai dengan Deteksi Dini terhadap Penyakit Payudara. Yogyakarta: Nuha Medika.

Puspitasari, E. (2018). Pengaruh Pemberian Susu Kedelai terhadap Peningkatan Produksi Asi pada Ibu Nifas di Rb Bina Sehat Bantul. Universitas Aisyiyah Yogyakarta.

Ulfiana, E. (2019). Pemberdayaan Kaum Ibu Melalui Pengolahan Susu Kedelai Sebagai Upaya Peningkatan Gizi Keluarga. Fakultas Keperawatan, Universitas Airlangga.

World Health Organization. (2018). Exclusive Breastfeeding for Optimal Growth Development and Health of Infants.

http://www.who.int/elena/titles/ex clusive breastfeeding/en/ 